\title{
INTEGRASI PENDIDIKAN KARAKTER DALAM PEMBELAJARAN DI MADRASAH DINIYAH
}

\author{
Abdul Wakid \\ Sekolah Tinggi IImu Budaya Islam (STIBI) Syekh Jangkung Pati \\ wahidnamira12@gmail.com
}

\begin{abstract}
ABSTRAK
Artikel ini ditulis untuk memberikan gambaran tentang pandangan konsepsional pendidikan karakterdalam pembelajaran di madrasah diniyah. Untuk memperoleh data tentang konsep pendidikan karakter penulis melakukan kajian kepustakaan. Madrasah diniyah merupakan sebuah lembaga pendidikan non-formal yangkeberadaannya sangat efektif untuk menambah pengetahuan agama anak didiknya, yang tidak diperoleh di bangku sekolah formal.Tujuan pembelajaran di Madrasah Diniyah bukan hanya pada pengetahuan dan keterampilan teknis (hard skill) saja, akan tetapi juga pada keterampilan mengelola diri dan orang lain (soft skill). Oleh karena itu, menjadi penting dalam pengembangan pendidikan karakter pada lembaga pendidikan madrasah diniyah, sebuah proses yang melibatkan penanaman pengetahuan, kecintaan dan penanaman perilaku kebaikan yang menjadi sebuah pola/kebiasaan. Nilai-nilai karakter yang dipandang ideal dan sangat penting diinternalisasikan ke dalam setiap jiwa peserta didik mencakup nilai-nilai berikut: religius, jujur, toleransi, disiplin, kerja keras, kreatif, mandiri, demokratis, rasa ingin tahu, semangat kebangsaan, cinta tanah air, menghargai prestasi, bersahabat/komunikatif, cinta damai, gemar membaca, peduli lingkungan, peduli sosial, dan tanggung jawab. Dalam hal ini, lembaga pendidikan madrasah diniyah harus mendesain proses pembelajaranmulai dari tahap perencanaan, pelaksanaan, hingga evaluasi pembelajaran pada semua mata pelajaran, sehingga menjadi bagian yang memberikan kontribusi positif terhadap pembinaan sikap/ karakter para peserta didik.
\end{abstract}

Kata Kunci: Pendidikan Karakter, Madrasah Diniyah.

\footnotetext{
ABSTRACT

This article was written to provide an overview of the conceptual views of character education in learning in madrasah diniyah. To obtain data about the concept of character education writers do literature review. Madrasah diniyah is a non-formal education institution whose existence is very effective to increase the religious knowledge of its students, which is not
} 
obtained in formal schooling. The learning objectives in Madrasah Diniyah are not only on the knowledge and technical skills (hard skills), but also on the skills of self-management and others (soft skills). Therefore, it becomes important in the development of character education in madrasah education institutions diniyah, a process that involves the cultivation of knowledge, love and cultivation of good behavior that becomes a pattern / habit. Values of character that are considered ideal and very important internalized into each student's soul include the following values: religious, honest, tolerance, discipline, hard work, creative, independent, democratic, curiosity, spirit of nationality, , appreciate achievement, friendly / communicative, love peace, love to read, care environment, social care, and responsibility. In this case, madrasah diniyah educational institutions should design the learning process from the planning stage, implementation, to the evaluation of learning on all subjects, so as to be a positive contribution to the guidance of the attitude / character of the learners.

Keywords: Character Education, Madrasah Diniyah. 


\section{PENDAHULUAN}

Madrasah di Indonesia memiliki sejarah yang cukup panjang, eksistensinya bermula pada abad ke-20. Dalam lintasan sejarah, eksistensi madrasah tidak lepas dari semangat pembaharuan pendidikan yang dipengaruhi oleh Islam Timur Tengah serta respon terhadap kebijakan pendidikan dari pemerintahan Hindia Belanda yang telah mengembangkan pendidikan dengan sistem persekolahan. Keberadaan Madrasah Diniyah dilatarbelakangi adanya keinginan dari masyarakat Islam untuk belajar secara seimbang antara ilmu agama dan ilmu pengetahuan umum.

Cikal bakal pendidikan Islam di Indonesia dimulai dengan keberadaan masjid, pesantren, surau (langgar) dan madrasah. Seiring dengan perkembangan zaman, maka fungsi dari lembaga-lembaga tersebut mengalami pergeseran. Namun pesantren dan madrasah sampai saat ini masih eksis sebagai lembaga pendidikan Islam.

Eksistensi madrasah dari masa ke masa semakin diakui oleh pemerintah dan masyarakat. Sebelum lahirnya UU. Sisdiknas No. 20 tahun 2003, Madrasah Diniyah (Madin) dikenal sebagai Madrasah (Haidar Daulay, 2009: 21). Madrasah memiliki karakteristik khusus ditinjau dari berbagai aspek. Madrasah selalu mengikuti perkembagan zaman, sehingga memunculkan model-model Madrasah dengan segala kekhasannya. Bahkan pemerintah mulai memperhatikan perkembangan Madrasah dengan memberikan pengakuan dan fasilitas. Jenjang pendidikan di Madrasah mulai dari pendidikan dasar, menengah,serta atas yaitu Madrasah Ibtidaiyah, Madrasah Tsanawiyah dan Madrasah Aliyah. Sedangkan Madrasah Diniyah dalam struktur pendidikan Islam di Indonesia masuk dalam kategori pendidikan non formal yang merupakan kelanjutan dari eksistensi madrasah pada awalnya.

Salah satu program utama pemerintah dalam rangka meningkatkan mutu proses dan output pendidikan adalah pengembangan pendidikan karakter. Sebenarnya pendidikan karakter bukan hal baru dalam sistem pendidikan Indonesia. Pada saat ini, setidaknya dalam pendidikan formal sudah ada mata pelajaran yang diberikan untuk membina akhlak dan budi pekerti peserta didik. Namun demikian, pembinaan karakter peserta didik melalui jalur pendidikan formal tersebut belum membuahkan hasil memuaskan.Sehingga pengembangan karakter perlu melibatkan jalur pendidikan lain, seperti pendidikan Madrasah Diniyah. Selain itu, kegiatan 
pembinaan kesiswaan dan pengelolaan Madrasah Diniyah juga perlu dirancang dan dilaksanakan untuk mendukung pendidikan karakter.

Dalam rangka pembentukan karakter peserta didik agar menjadi pribadi yangberiman, memiliki etika, dan sopan santun dalam berinteraksi dengan siapa pun, maka pendidikan harus diintegrasikan dengan pendidikan karakter di dalamnya.Pendidikan karakter seharusnya membawa peserta didik pada pengenalan nilai secara kognitif, penghayatan nilai secara afektif, dan akhirnya pada pengamalan nilai secara nyata. Inilah rancangan pendidikan karakter (moral) yang digagas oleh Thomas Lickona disebut moral knowing, moral feeling, dan moral action (Lickona, 1991: 51). Oleh karena itu, pendidikan Madrasah Diniyah harus bermuatan pendidikan karakter yang membawa peserta didik menjadi manusia berkarakter seperti yang ditegaskan oleh Lickona tersebut.

\section{PEMBAHASAN}

\section{Konsep Pendidikan Karakter}

Secara etimologis, kata karakter (Inggris: character) berasal dari bahasa Yunani, yaitu charassein yang berarti "to engrave" (Ryan \& Bohlin, 1999: 5). Kata "to engrave" dapat diartikan mengukir, melukis, memahatkan, atau menggoreskan (Echols \& Shadily, 1995: 214). Hal ini dapat dijelaskan kehidupan seseorang diibararatkan sebuah patung yang sedang dipahat, jika dipahatnya dilakukan secara sembarangan tanpa aturan, maka akan menghasilkan patung yang jelek/ rusak. Begitu juga dengan karakter seorang anak, jika kita membentuknya dengan cara sembarangan maka karakter anak tersebut akan rusak pula.

Dalam Kamus Bahasa Indonesia kata "karakter" diartikan dengan tabiat, sifatsifat kejiwaan, akhlak atau budi pekerti yang membedakan seseorang dengan yang lain, dan watak. Karakter juga bisa berarti huruf, angka, ruang, simbul khusus yang dapat dimunculkan pada layar dengan papan ketik (Pusat Bahasa Depdiknas, 2008: 682). Orang berkarakter berarti orang yang berkepribadian, berperilaku, bersifat, bertabiat, atau berwatak.Hal tersebut dapat dipahami bahwa karakter dapat diidentikkan dengan kepribadian atau akhlak. Kepribadian merupakan ciri, karakteristik, atau sifat khas diri seseorang yang bersumber dari bentukan-bentukan yang diterima dari lingkungan, misalnya keluarga pada masa kecil dan bawaan sejak lahir (Doni Koesoema, 2007: 80). 
Makna karakter secara terminologis, menurut Thomas Lickona adalah " $A$ reliable inner disposition to respond to situations in a morally good way." Selanjutnya, Lickona menambahkan, "Character so conceived has three interrelated parts: moral knowing, moral feeling, and moral behavior" (Lickona, 1991: 51). Menurut Lickona, karakter mulia (good character) meliputi pengetahuan tentang kebaikan (moral khowing), lalu menimbulkan komitmen (niat) terhadap kebaikan (moral feeling), dan akhirnya benar-benar melakukan kebaikan (moral behavior). Dengan kata lain, karakter mengacu kepada serangkaian pengetahuan (cognitives), sikap (attitudes), dan motivasi (motivations), serta perilaku (behaviors) dan keterampilan (skills).

Menurut Helen G. Douglas dalam bukunya Muchlas Samami \& Harianto (2011: 45) menyatakan: Character isn't inherited. One builds it daily by the way one thinks and acts, thought by thought, action by action. Karakter tidak diwariskan, tapi ia dibangun secara berkesinambungan hari demi hari, melalui pikiran dan perbuatan, pikiran demi pikiran, tindakan demi tindakan.

Dari pengertian di atas dapat dipahami bahwa karakter sebagai nilai dasar yang membangun pribadi seseorang, terbentuk baik karena pengaruh hereditas maupun pengaruh lingkungan, yang membedakannya dengan orang lain, serta diwujudkan dalam sikap dan perilakunya sehari-hari baik dalam rangka berhubungan dengan Tuhan, dengan diri sendiri, dengan sesama manusia, maupun dengan lingkungan, yang terwujud dalam pikiran, sikap, perasaan, perkataan, dan perbuatan berdasarkan norma-norma agama, hukum, tata karma, budaya, dan adat istiadat.Individu yang berkarakter baik adalah yang dapat membuat keputusan dan siap mempertanggungjawabkan setiap akibat dari keputusannya. Ciri ini lahir dari konsekuensi pemaknaan karakter sebagai cara berpikir dan berperilaku yang khas tiapindividu untuk hidup dan bekerja sama, baik dalam lingkup keluarga, masyarakat, bangsa, dan negara.

Dari konsep karakter ini muncul konsep pendidikan karakter (character education).Terminologi pendidikan karakter mulai dikenal sejak tahun 1900-an. Thomas Lickona dianggap sebagai pengusungnya, terutama ketika ia menulis buku yang berjudul The Return of Character Education dan kemudian disusul bukunya yang berjudul, Educating for Character: How Our School Can Teach Respect and Responsibility. Melalui buku-bukunya itu, Lickona menyadarkan pada dunia Barat akan pentingnya pendidikan karakter, di mana pendidikan karakter menurutnya mengandung tiga unsur pokok, yaitu mengetahui kebaikan (knowing the good), 


\section{6 | Jurnal Tarbawi Vol. 15. No. I. Januari - Juni 2018}

mencintai kebaikan (desiring the good), dan melakukan kebaikan (doing the good) (Lickona, 1991: 51).Di sisi yang lain, Berkowitz \& Bier (2005: 7) berpendapat bahwa pendidikan karakter merupakan penciptaan lingkungan sekolah yang membantu peserta didik dalam perkembangan etika, tanggung jawab melalui model dan pengajaran karakter yang baik melalui nilai-nilai universal.

Maka pendidikan karakter harus menjadi gerakan nasional yang menjadikan Madrasah Diniyah sebagai agen untuk membangun karakter siswa melalui pembelajaran dan pemodelan. Melalui pendidikan karakter Madrasah Diniyah harus berpretensi untuk membawa peserta didik memiliki nilai-nilai karakter mulia seperti hormat dan peduli pada orang lain, tanggung jawab, memiliki integritas, dan disiplin. Di sisi lain pendidikan karakter juga harus mampu menjauhkan peserta didik dari sikap dan perilaku yang tercela dan dilarang.

Pendidikan karakter dapat dimaknai dengan suatu sistem penanaman nilai-nilai karakter kepada warga Madrasah yang meliputi komponen pengetahuan, kesadaran, atau kemauan, dan tindakan untuk melaksanakan nilai-nilai tersebut baik terhadap Tuhan Yang Maha Esa, diri sendiri, sesama, lingkungan, maupun kebangsaan sehingga menjadi manusia insan kamil.Dengan demikian, pendidikan karakter membawa misi yang sama dengan pendidikan akhlak atau pendidikan moral. Selanjutnya Frye (2002: 3) juga menjelaskan bahwa pendidikan karakter merupakan usaha yang disengaja untuk membantu seseorang memahami, menjaga, dan berperilaku yang sesuai dengan nilai-nilai karakter mulia.

Pendidikan karakter memiliki tujuan penanaman nilai dalam diri siswa dan pembaruan tata kehidupan bersama yang lebih menghargai kebebasan individu. Selain itu meningkatkan mutu penyelenggaraan dan hasil pendidikan di madrasah yang mengarah pada pencapaian pembentukan karakter dan akhlak mulia peserta didik secara utuh, terpadu, dan seimbang sesuai dengan standar kompetensi lulusan. Ada banyak nilai karakter yang dapat dikembangkan dan diintegrasikan dalam pembelajaran. Menanamkan semua butir nilai tersebut merupakan tugas yang sangat berat. Oleh karena itu, perlu dipilih nilai-nilai tertentu yang diprioritaskan penanamannya pada peserta didik.

Nilai-nilai pendidikan karakter yang dikembangkan Kementerian Pendidikan ada delapan belas karakter. Nilai-nilai tersebut bersumber dari agama, pancasila, budaya, dan tujuan pendidikan nasional. Adapun delapan belas nilai tersebut yaitu: religius, jujur, toleransi, disiplin, kerja keras, kreatif, mandiri, demokratis, rasa ingin 
tahu, semangat kebangsaan, cinta tanah air, menghargai prestasi, bersahabat/komunikatif, cinta damai, gemar membaca, peduli lingkungan, peduli sosial, dan tanggung jawab (Pusat Kurikulum Kementerian Pendidikan Nasional, 2009: 9-10).

Dari delapan belas nilai karakter di atas, seorang pendidik dapat memilih nilainilai karakter tertentu untuk diterapkan pada peserta didik disesuaikan dengan muatan materi dari setiap mata pelajaran yang ada. Kementerian Pendidikan Nasional mencanangkan empat nilai karakter utama yang menjadi ujung tombak penerapan karakter di kalangan peserta didik, yakni kejujuran, ketangguhan, kepedulian, dan kecerdasan.

\section{Sekilas tentang Madrasah Diniyah}

Secara yuridis, dasar pendidikan Madrasah Diniyah adalah UU No. 20 Tahun 2003, PP Nomor 19 tahun 2005, PP No. 55 Tahun 2007 tentang Pendidikan Agama dan Keagamaan, dikuatkan dengan Peraturan Menteri Agama Nomor 10 tahun 2010 tentang Organisasi dan Tata Kerja Kementrian Agama. Madrasah Diniyah sebagai lembaga pendidikan Islam legitimasinya telah diakui oleh pemerintah Indonesia. Legitimasi tersebut direalisasikan dalam Peraturan Pemerintah Republik Indonesia Nomor 55 Tahun 2007 Tentang Madrasah Diniyah Non-formal. Pada pasal 21 disebutkan bahwa: 1). Pendidikan diniyah non-formal diselenggarakan dalam beberapa bentuk diantaranya pengajian kitab, Majelis Taklim, Pendidikan Al Qur'an, Diniyah Takmiliyah, atau sejenis; 2). Pendidikan diniyah non-formal sebagaimana dimaksud pada ayat 1 dapat berbentuk satuan pendidikan; 3). Pendidikan diniyah non-formal yang sudah berkembang untuk menjadi satuan pendidikan wajib mendapatkan izin dari kantor Departemen Agama Kabupaten/Kota setelah memenuhi ketentuan persyaratan pendirian satuan pendidikan.

Keberadaan peraturan perundangan tersebut, menjadikan lembaga pendidikan Madrasah Diniyah memiliki payung hukum jelas dalam proses pembelajarannya. Sekaligus memperkuat status dan legalitas Madrasah Diniyah. Karena selama ini, penyelenggaraan pendidikan Madrasah Diniyah tidak banyak diketahui bagaimana pola pengelolaannya. Tetapi karakteristiknya yang khas menjadikan Madrasah Diniyah layak untuk dipertahankan eksistensinya.

Adanya payung hukum yang jelas untuk Madrasah Diniyah, berarti standar pendidikan dalam pembelajarannyapun wajib mengikuti aturan pemerintah. Hal ini 
merujuk pada standar pemerintah yang tertuang dalam Keputusan Direktorat Jenderal Pendidikan Agama Islam Nomor: 3203 Tahun 2013 tentang Standar Proses Pengelolaan dan Penilaian Pendidikan Madrasah Diniyah Takmiliyah, yaitu adanya perencanaan pembelajaran, pelaksanaan pembelajaran, dan kegiatan penutup (Kementerian Agama RI, 2013: 11-19).

Sementara dalam Peraturan Menteri Agama Republik Indonesia Nomor 3 Tahun 1983 Tentang Kurikulum Madrasah Diniyah dalam BAB 1 pasal 1, menyebutkan bahwa Madrasah Diniyah adalah lembaga pendidikan dan pengajaran agama Islam, yang berfungsi terutama untuk memenuhi hasrat orang tua agar anakanak lebih banyak mendapat pendidikan Agama Islam (Departemen Agama Islam RI., 1983/1984: 1-3). Dijelaskan pula, bahwa fungsi pendidikan Madrasah Diniyah adalah: (1) Membina perkembangan kepribadian anak; (2) Memberi tuntunan dan pembinaan kesejahteraan anak; (3) Memberi pendidikan agama pada anak; (4) Membantu rumah tangga/keluarga untuk memenuhi kebutuhan anaknya; (5) Membantu meningkatkan serta memajukan keluarga dan masyarakat; (6) Membantu peningkatan pendidikan agama pada sekolah umum; dan (7) Memberi pendidikan dan tuntutan kepada anak dalam hal kependudukan dan lingkungan hidup (Departemen Agama Islam RI., 1983/1984: 15-16).

Madrasah Diniyah sebagai lembaga pendidikan non-formal, keberadaannya sangat efektif untuk menambah pengetahuan agama para anak didiknya, yang tidak diperoleh di bangku sekolah formal.Sebagai salah satu jenis satuan pendidikan keagamaan, Madrasah Diniyah tetap mempertahankan ciri khasnya sebagai lembaga pendidikan Islam dengan memberikan mata pelajaran agama, misalnya al-Quran, Hadits, Fiqh, Akhlak, sejarah Islam, bahasa Arab, dan lain sebagainya.

Namun, pada dasarnya kurikulum Madrasah Diniyah bersifat fleksibel dan akomodatif. Oleh karena itu, pengembangannya dapat dilakukan oleh Departemen Agama Pusat, Kantor Wilayah Propinsi dan Kantor Departemen Agama Kabupaten/Kotamadya atau oleh pengelola kegiatan pendidikan itu sendiri. Prinsip pokok untuk mengembangkan tersebut ialah tidak menyalahi aturan perundangundangan yang berlaku tentang pendidikan secara umum, peraturan pemerintah, keputusan Menteri Agama dan kebijakan lainnya yang berkaitan dengan penyelenggaraan pendidikan Madrasah Diniyah. 


\section{Integrasi pendidikan karakter dalam pembelajaran di Madrasah Diniyah}

Integrasi pendidikan karakter dalam proses pembelajaran dapat dilakukan dalam substansi materi, pendekatan, metode, dan model evaluasi yang dikembangkan. Tidak semua substansi materi pelajaran cocok untuk semua karakter yang akan dikembangkan, perlu dilakukan seleksi materi dan sinkronisasi dengan karakter yang akan dikembangkan. Pada prinsipnya semua mata pelajaran dapat digunakan sebagai alat untukmengembangkan semua karakter peserta didik, namun agar tidak terjadi tumpang-tindih dan terabaikannya salah satu karakter yang akan dikembangkan, perlu dilakukan pemetaan berdasarkan kedekatan materi dengan karakter yang akan dikembangkan.

Sebagaimana yang dituangkan dalam Desain Induk Pendidikan Karakter (2010: 28), Proses integrasi pendidikan karakter dalam pembelajaran di Madrasah Diniyah dapat dilakukan melalui:
a. Kegiatan pembelajaran di kelas
b. Pengembangan budaya satuan pendidikan
c. Kegiatan ko-kurikuler
d. Kegiatan ekstrakurikuler (Kementerian Pendidikan Nasional, 2011: 67)

Selanjutnya langkah-langkah pengintegrasian pendidikan karakter dalam pembelajaran di Madrasah Diniyah dapat dilakukan dengan langkah-langkah sebagai berikut:

a. Mendiskripsikan kompetensi dasar tiap mata pelajaran

b. Mengidentifikasi aspek-aspek atau materi-materi pendidikan karakter yang akan diintegrasikan ke dalam mata pelajaran

c. Mengintegrasikan butir-butir karakter/ nilai ke dalam kompetensi dasar (materi pembelajaran) yang dipandang relevan atau ada kaitannya

d. Menentukan metode pembelajaran

e. Menentukan evaluasi pembelajaran

f. Menentukan sumber belajar (Majid \&Andayani, 2011: 170-171). 
IO | Jurnal Tarbawi Vol. I5. No. I. Januari - Juni 2018

Adapun nilai-nilai karakter yang terkandung dalam pembelajaran di Madrasah Diniyah dapat dikelompokkan sebagai berikut:

\begin{tabular}{|c|c|c|}
\hline $\begin{array}{l}\text { Jangkauan } \\
\text { Sikap Dan } \\
\text { Perilaku }\end{array}$ & Nilai-Nilai Pendidikan Karakter & $\begin{array}{c}\text { Nilai-Nilai Karakter Dalam } \\
\text { pembelajaran di Madrasah } \\
\text { Diniyah }\end{array}$ \\
\hline $\begin{array}{l}\text { Terhadap } \\
\text { Tuhan }\end{array}$ & $\begin{array}{l}\text { Religius (cinta Tuhan dan } \\
\text { segenap ciptaannya) }\end{array}$ & $\begin{array}{l}\text { Iman, takwa, syukur, ikhlas, } \\
\text { sabar, taat, taubat }\end{array}$ \\
\hline \multirow{4}{*}{$\begin{array}{l}\text { Terhadap } \\
\text { diri sendiri }\end{array}$} & Mandiri, tanggung jawab & $\begin{array}{lrr}\text { Berusaha } & \text { keras } & \text { untuk } \\
\text { mencapai } & \text { prestasi terbaik, } \\
\text { disiplin } & & \end{array}$ \\
\hline & Jujur/amanah & $\begin{array}{l}\text { Jujur, adil, amanah, terbuka, } \\
\text { konsisten }\end{array}$ \\
\hline & Hormat, santun & Hormat, respect, santun \\
\hline & Baik dan rendah hati & $\begin{array}{l}\text { Sopan, santun, bekerja sama, } \\
\text { kasih sayang }\end{array}$ \\
\hline \multirow{2}{*}{$\begin{array}{l}\text { Terhadap } \\
\text { sesama }\end{array}$} & Kepemimpinan dan keadilan & $\begin{array}{l}\text { Adil, jujur, tanggung jawab, } \\
\text { toleran terhadap perbedaan }\end{array}$ \\
\hline & $\begin{array}{l}\text { Demawan, suka menolong, dan } \\
\text { kerja keras }\end{array}$ & $\begin{array}{l}\text { Gotong royong, Bekerja sama, } \\
\text { tolong menolong, tidak egoistis }\end{array}$ \\
\hline $\begin{array}{l}\text { Terhadap } \\
\text { lingkungan }\end{array}$ & Peduli sosial dan lingkungan & $\begin{array}{l}\text { Tertib, disiplin, menjaga diri } \\
\text { dan lingkungan }\end{array}$ \\
\hline $\begin{array}{l}\text { Terhadap } \\
\text { kebangsaan }\end{array}$ & $\begin{array}{l}\text { Toleransi, kedamaian, dan } \\
\text { kesatuan }\end{array}$ & $\begin{array}{l}\text { Setia, peduli, menghargai } \\
\text { keberagaman }\end{array}$ \\
\hline
\end{tabular}

Berdasarkan tabel di atas, dapat dilihat bahwatujuan pembelajaran di Madrasah Diniyah bukan hanya pada pengetahuan dan keterampilan teknis (hard skill)saja, akan tetapi juga pada keterampilan mengelola diri dan orang lain (soft skill). Jadi di dalam pendidikan karakter dalam pembelajaran di Madrasah Diniyah mengandung nilai-nilai karakter baik yang berhubungan dengan Tuhan (hablum minallah), diri sendiri (hablum minannafsi), sesama manusia (hablum minan-nas), lingkungan (hablum minal 'alam) dan kebangsaan.

Dalam bentuk inovasi yang paling penting dan langsung bersentuhan dengan aktivitas pembelajaran sehari-hari adalah pengintegrasian pendidikan karakter dalam 
proses pembelajaran. Integrasi pendidikan karakter dalam proses pembelajaran di Madrasah Diniyah dapat dilaksanakan mulai dari tahap perencanaan, pelaksanaan, hingga evaluasi pembelajaran pada semua mata pelajaran.

\section{a. Tahap Perencanaan Pembelajaran}

Pada tahap perencanaan pembelajaran di Madrasah diniyah yang perlu dilakukan adalah menganalisis semua komponen dalam kegiatan pembelajaran, yaitu menganalisis SK/KD (Standar Kompetensi/Kompetensi Dasar), pengembangan silabus, penyusunan RPP (Rancangan Pelaksanaan Pembelajaran), serta penyiapan bahan ajar. Analisis tersebut penting dilakukan untuk mengidentifikasi nilai-nilai karakter yang secara substansi dapat diintegrasikan pada komponen kegiatan pembelajaran. Identifikasi nilai-nilai karakter ini tidak dimaksudkan untuk membatasi nilai-nilai yang dapat dikembangkan pada kegiatan pembelajaran.

Langkah-langkah yang dapat dilakukan dalam menganalisis pada tahap perencanaan kegiatan pembelajaran adalah:

1) Analisis SK/KD, yaitu mengidentifikasi nilai-nilai karakter yang secara substansi dapat diintegrasikan pada SK/KD yang bersangkutan.

2) Pengembangan silabus. Dalam pengembangan silabus, kegiatan pembelajaran, indikator pencapaian, dan/atau teknik penilaian, harus dirumuskan ulang dengan menyesuaikan terhadap karakter yang hendak dikembangkan. Setelah itu, merevisi silabus dengan menambah komponen karakter yang diisi dengan nilai-nilai karakter yang hendak diintegrasikan dalam pembelajaran.

3) Merevisi RPP. Terdapat beberapa langkah yang dapat dilakukan dalam merevisi RPP, yaitu; pertama, merumuskan tujuan pembelajaran pada pengembangan kemampuan kognitif, psikomotorik, dan karakter dengan cara menambah tujuan pembelajaran yang secara khusus dirumuskan untuk karakter. Kedua, pendekatan dan metode pembelajaran harus dapat memfasilitasi peserta didik agar dapat mencapai tujuan pembelajaran, yaitu pengetahuan, keterampilan serta pengembangan karakter. Ketiga, kegiatan pembelajaran pada tahapan pendahuluan, inti dan penutup harus disesuaikan agar dapat memfasilitasi peserta didik memperoleh pengetahuan, keterampilan, dan pengembangan karakter yang telah ditargetkan. Keempat, teknik penilaian harus dirumuskan dan disesuaikan sehingga benar-benar dapat mengukur pencapaian peserta didik dalam kompetensi dan karakter. 
I2 | Jurnal Tarbawi Vol. I5. No. I. Januari - Juni 2018

Kelima, mengadaptasi buku ajar yang dipakai dengan cara merevisi atau menambah nilai-nilai karakter ke dalam pembahasan materi yang ada di dalamnya.

\section{b. Tahap Pelaksanaan Pembelajaran}

Pada tahap pelaksanaan pembelajaran, kegiatan pembelajaran harus dikembangkan secara sistematis, efektif dan efisien dan juga perlu variasi kegiatan sebagai alternatif untuk menumbuh kembangkan motivasi dan aktifitas siswa dalam belajar sehingga dapat memfasilitasi terinternalisasinya nilai-nilai karakter pada peserta didik.

Ada tiga tahapan dalam pelaksanaan pembelajaran di Madrasah Diniyah:

1) Kegiatan pra dan awal pembelajaran

Kegiatan pendahuluan dalam pembelajaran sering disebut dengan prainstruksional. Fungsi utama kegiatan tersebut adalah untuk menciptakan awal pembelajaran yang efektif yang memungkinkan siswa dapat mengikuti proses pembelajaran dengan baik. Upaya yang dapat dilakukan untuk mewujudkan kondisi awal pembelajaran yang baik di Madrasah Diniyah sehingga dapat memfasilitasi terinternalisasinya nilai-nilai karakter pada peserta didik adalah; pertama, menciptakan sikap dan suasana kelas yang menarik. Kedua, menciptakan kesiapan belajar siswa. Ketiga, menciptakan suasana belajar yang demokratis. Keempat, melaksanakan kegiatan apersepsidan atau melaksanakan tes awal.

2) Kegiatan inti pembelajaran

Pada hakikatnya kegitan inti pembelajaran merupakan implementasi strategi dan pendekatan belajar. Secara sistematis langkah kegiatan inti yang harus dilakukan dalam pembelajaran di Madrasah Diniyah sehingga dapat memfasilitasi terinternalisasinya nilai-nilai karakter pada peserta didik adalah; pertama, memberitahukan tujuan atau garis besar materi dan kemampuan yang akan dipelajari. Kedua, menyampaikan alternatif kegiatan belajar yang akan ditempuh peserta didik. Ketiga, membahas materi atau menyajikan bahan ajar. Keempat, menyimpulkan pelajaran.

3) Kegiatan akhir pembelajaran/ penutup

Kegiatan akhir pembelajaran tidak hanya diartikan sebagai kegiatan untuk menutup pelajaran, tetapi juga sebagai kegiatan penilaian hasil belajar peserta didik dan kegiatan tindak lanjut. Kegiatan tindak lanjut harus ditempuh 
berdasarkan pada proses dan hasil belajar peserta didik. Kegiatan akhir dan tindak lanjut pembelajaran yang ada di Madrasah Diniyah yang harus dilakukan adalah; Pertama, menilai hasil proses belajar mengajar. Kedua, memberikan tugas atau latihan yang dikerjakan diluar jam pelajaran. Ketiga, memberikan motivasi dan bimbingan belajar. Keempat, menyampaikan alternatif kegiatan belajar yang dapat dilakukan peserta didik di luar jam pelajaran. Kelima, berdasarkan hasil penilaian peserta didik, kemungkinan peserta didik harus diberikan program pembelajaran secara perorangan atau kelompok untuk melaksanakan program pengayaan dan atau perbaikan yang dilakukan di luar jam pelajaran.

Kegiatan pembelajaran di Madrasah Diniyah tersebut, mulai tahapan kegiatan pendahuluan, inti, dan penutup, dipilih dan dilaksanakan agar peserta didik mempraktikkan nilai-nilai karakter yang ditargetkan.Selain itu, perilaku guru sepanjang proses pembelajaran harus merupakan model pelaksanaan nilai-nilai karakter bagi peserta didik.

\section{c. Tahap Evaluasi Pembelajaran}

Evaluasi adalah kegiatan akhir yang harus dilakukan oleh seorang pendidik untuk mengetahui seberapa jauh penguasaan materi oleh peserta didik. Evaluasi pembelajaran yang ada di Madrasah diniyah digunakan oleh seorang pendidik untuk mengetahui seberapa jauh terinternalisasinya nilai-nilai karakter kepada peserta didik.Dalam pendidikan karakter, evaluasi harus dilakukan dengan baik dan benar.Penilaian karakter lebih mementingkan pencapaian afektif dan psikomotorik peserta didik dibandingkan dengan pencapaian kognitifnya.

Agar hasil penilaian yang dilakukan oleh seorang pendidik di Madrasah Diniyah bisa benar dan objektif, maka seorang pendidik harus memahami prinsip-prinsip penilaian yang benar, yaitu:

1) Prinsip berkelanjutan, yaitu dimaksudkan bahwa evaluasi tidak hanya dilakukan sekali dalam jenjang pembelajaran. Akan tetapi harus dilakukan setiap saat dan setiap waktu. Jadi dengan evaluasi secara kontinu maka perkembangan anak didik dapat terkontrol dengan baik.

2) Prinsip universal, yaitu dimaksudkan evaluasi hendaknya dilakukan untuk semua aspek sasaran pembelajaran yaitu aspek kognitif, afektif dan psikomotorik. 
3) Prinsip keikhlasan, dalam hal ini keikhlasan pendidik harus tercermin disegala aktifitasnya dalam mendidik, termasuk juga dalam mengevaluasi pembelajaran. Pendidik yang ikhlas dalam mengevaluasi akan terlihat dari sikapnya yang transparan dan obyektif. Pendidik tidak hanya mampu menunjukkan kesalahan-kesalahan peserta didik tetapi juga mampu menunjukkan jalan keluarnya, sehingga peserta didik tidak merasa dipersulit oleh pendidik.

Selain prinsip-prinsip di atas, terdapat juga prinsip-prinsip evaluasi secara umum, yaitu prinsip keterpaduan, prinsip keterlibatan peserta didik, prinsip koherensi evaluasi, prinsip pedagogis dan prinsip akuntabel.

Selain memahami prinsip-prinsip evaluasi pembelajaran, pendidik di Madrasah Diniyah juga harus memahami dan menguasai teknik-teknik evaluasi dalam pembelajaran agar supaya seorang pendidik bisa tepat dalam mengukur hasil belajar peserta didik, utamanya dalam mengukur karakternya. Teknik evaluasi yang harus dipahami dan dikuasai oleh seorang pendidik di Madrasah Diniyah adalah:

1) Teknik tes, yaitu penilaian yang menggunakan tes yang telah ditentukan terlebih dahulu. Metode ini bertujuan untuk mengukur dan memberikan penilaian terhadap hasil belajar yang dicapai oleh peserta didik meliputi; kesanggupan mental, penguasaan hasil belajar, keterampilan, koordinasi, motorik dan bakat individu/ kelompok.

2) Teknik non-tes, yaitu penilaian yang tidak menggunakan soal-soal tes. Hal ini bertujuan untuk mengetahui sikap dan sifat kepribadian peserta didik yang berhubungan dengan kiat belajar atau pendidikan, obyek penilaian non-tes ini meliputi; perbuatan, ucapan, kegiatan, pengalaman, keadaan, tingkah laku, riwayat hidup, baik bersifat individu atau kelompok.

\section{KESIMPULAN}

Dari pembahasan mengenai integrasi pendidikan karakter dalam pembelajaran di Madrasah Diniyah ini dapat disimpulkan bahwa Madrasah Diniyah adalah sebuah lembaga pendidikan non-formal, yang keberadaannya sangat efektif untuk menambah pengetahuan agama kepada para anak didiknya, yang tidak diperoleh di bangku sekolah formal.Sebagai salah satu jenis satuan pendidikan keagamaan, Madrasah Diniyah tetap mempertahankan ciri khasnya sebagai lembaga pendidikan Islam dengan memberikan mata pelajaran agama. 
Pengintegrasian nilai-nilai karakter pada lembaga pendidikan non-formal Madrasah Diniyah dapat dilakukan dalam kegiatan pembelajaran di kelas, pengembangan budaya satuan pendidikan, kegiatan ko-kurikuler, dan kegiatan ekstrakurikuler. Sedangkan dalam bentuk inovasi yang langsung bersentuhan dengan aktivitas pembelajaran sehari-hari adalah pengintegrasian pendidikan karakter dalam proses pembelajaran.

Integrasi pendidikan karakter dalam proses pembelajaran di Madrasah Diniyah dapat dilaksanakan mulalui tiga tahapan, yaitu; pertama, tahap perencanaan pembelajaran , meliputi; menganalisis SK/KD, pengembangan silabus, penyusunan RPP, dan penyiapan bahan ajar. Kedua, tahap pelaksanaan pembelajaran, meliputi; kegiatan pendahuluan, kegiatan inti dan kegiatan penutup. Ketiga, tahap evaluasi pembelajaran, hal ini berdasar pada prinsip dan teknik evaluasi pembelajaran sesuai dengan standar penilaian yang telah ditetapkan oleh pemerintah dan para ahli penilaian agar memperoleh hasil penilaian yang benar dan obyektif.

\section{DAFTAR PUSTAKA}

Berkowitz, M.W, and Bier, Melinda, C. 2005. What Works In Character Education: A Research-driven guide for educators, Washington, DC: Univesity of MissouriSt Louis.

Daulay, Haidar Putra. 2001. Historisitas dan Efisiensi Pesantren sekolah dan Madrasah. Yogyakarta: PT Tiara Wacana.

Departemen Agama Islam RI.1983/1984.Kurikulum Madrasah Diniyah Ulya.

Echols, M. John \& Shadily, H. 1995. Kamus Inggris Indonesia: An EnglishIndonesian Dictionary. Jakarta: PT Gramedia. Cet. XXI.

Frye, Mike at all. (Ed.) 2002. Character Education: Informational Handbook and Guide for Support and Implementation of the Student Citizent Act of 2001. North Carolina: Public Schools of North Carolina.

Kementerian Agama RI Direktorat Jenderal Pendidikan Islam. 2013. Standar Proses Pengelolaan Dan Penilaian Pendidikan Madrasah Diniyah Takmiliyah.

Koesoema, Doni. 2007.Pendidikan Karakter: Strategi Mendidik Anak di Zaman Global, Jakarta: Grasindo.

Lickona, Thomas. 1991. Educating for CharacterHow Our School Can Teach Respect and Responsibility. New York, Toronto, London, Sydney, Aucland: Bantam books. 
16 | Jurnal Tarbawi Vol. 15. No. I. Januari - Juni 2018

Majid, Abdul dan Andayani, Dian. 2011.Pendidikan Karakter Perspektif Islam, Bandung: PT Remaja Rosdakarya.

Pusat Bahasa Departemen Pendidikan Nasional. 2008. Kamus Bahasa Indonesia. Jakarta: Pusat Bahasa. Cet. I.

Pusat Kurikulum Balitbang Kemdiknas. 2009.Pengembangan dan Pendidikan Budaya \& Karakter Bangsa: Pedoman Sekolah, Jakarta: Puskur Balitbang Kemdiknas.

Ryan, Kevin \& Bohlin, K. E. 1999. Building Character in Schools: Practical Ways to Bring Moral Instruction to Life. San Francisco: Jossey Bass.

Samani, Muchlas dan Hariyanto. 2011.Konsep dan Model Pendidikan Karakter, Bandung: Remaja Rosdakarya. 